\title{
Stopover behavior of Red-eyed Vireos (Vireo olivaceus) during fall migration on the coast of the Yucatan Peninsula
}

\author{
Richard Evan Feldman ${ }^{*}$ (D), Antonio Celis-Murillo ${ }^{2,3}$, Jill L. Deppe ${ }^{4}$ and Michael P. Ward ${ }^{2,5}$
}

\begin{abstract}
Background: For migrating birds, stopover requires spending time and energy that otherwise could be allocated to flying. Thus, birds optimally refuel their subsequent migratory flight by reducing stopover duration or foraging activity in food-rich environments. In coastal habitats, birds may forego refueling and take short stopovers irrespective of local food availability. Given the paucity of studies exploring how migrants adjust stopover behavior in response to temporal variation in food availability, especially in the Neotropics, we fixed radio tags to 51 Red-eyed Vireos (Vireo olivaceous) over two years at two sites on the coast of Mexico's Yucatan Peninsula.
\end{abstract}

Methods: We applied VHF radio tags during the fall of 2016 and 2017, and tracked birds using automatic and manual receiving units. We estimated stopover duration and activity levels (one site only) for between six and fifteen birds, depending on site and year. We measured fruit availability weekly along the net lanes where we captured birds. We used a generalized linear model to estimate the relationships between stopover duration/activity level and fruit density, bird body mass and year. We interpreted relationships for the model with the lowest AlCc value.

Results: We found that approximately half of the birds departed on the same day they were captured. For the birds that stayed longer, we could not discern whether they did so because they were light, or fruit density was high. On the other hand, lighter birds were more active than heavier birds but only in one of the two years.

Conclusions: Given our results, it is unlikely that Red-eyed Vireos refuel along the Yucatan coast. However, they still likely need to recuperate from crossing the Gulf of Mexico, which may necessitate foraging more often if in poor body condition. If the birds then move inland then stopover should be thought of as a large-scale phenomenon, where habitats with different functions may be spread out over a broad landscape.

Keywords: Coastal dune, Fruit, Geographic barrier, Gulf of Mexico, Phenology, Stopover, Time-minimization

\section{Background}

Migration is a critical stage in the life cycle of many bird species. Long flights, large distances, and unpredictable weather mean migrating birds incur a high mortality risk (Sillett and Holmes 2002). For a successful migration, birds must rest in stopover habitats where they may also

*Correspondence: richard.feldman@cicy.mx

${ }^{1}$ Centro de Investigación Científica de Yucatán, Unidad de Recursos Naturales, Merida, Yucatán, Mexico

Full list of author information is available at the end of the article deposit the fat mass needed to fuel subsequent flights (Bairlein 2002; McWilliams et al. 2004) and rebuild muscle mass lost during previous flights (Skrip et al. 2015). In most cases, birds aim to minimize overall migration time (Alerstam and Lindström 1990; Alerstam 2011) possibly to arrive early to their breeding (Paxton and Moore 2015) and wintering grounds (La Sorte et al. 2015). Early arrival often increases fecundity and adult survival (Marra et al. 1998; Norris et al. 2004; Smith and Moore 2005; Reed et al. 2013). Hence, in terms of individual fitness, it is advantageous for birds to minimize stopover original author(s) and the source, provide a link to the Creative Commons licence, and indicate if changes were made. The images or other third party material in this article are included in the article's Creative Commons licence, unless indicated otherwise in a credit line to the material. If material is not included in the article's Creative Commons licence and your intended use is not permitted by statutory regulation or exceeds the permitted use, you will need to obtain permission directly from the copyright holder. To view a copy of this licence, visit http://creativecommons.org/licenses/by/4.0/. The Creative Commons Public Domain Dedication waiver (http://creativeco mmons.org/publicdomain/zero/1.0/) applies to the data made available in this article, unless otherwise stated in a credit line to the data. 
duration and/or the overall number of stopovers made during migration (Schaub et al. 2008; Alerstam 2011). When refueling, birds can speed migration by stopping over just long enough to maximize their departure fuel load with the exact duration dependent on fuel deposition rate (Alerstam and Hedenström 1998; Hedenström 2008). While some studies have shown that deposition rate should be higher where food is more plentiful (Loria and Moore 1990; Dänhardt and Lindström 2001; Bairlein 2002), there have been very few studies explicitly testing how birds alter stopover behavior in response to naturally varying food availability.

Given that individuals of many bird species deposit fuel in the form of fat and protein (Bairlein 1998; Marshall et al. 2016), it is not surprising that several studies have demonstrated individual selection for food-rich habitats (Cohen et al. 2012) and positive associations between bird abundance and local arthropod availability and landscape-level forest cover (Buler et al. 2007; Buler and Moore 2011; McCabe and Olsen 2015a). During fall migration, many birds consume fruit for their sugars, fatty acids (Wheelwright 1988; Bairlein 1996; McWilliams et al. 2002; Smith and McWilliams 2010) and antioxidants (Alan et al. 2013; Bolser et al. 2013; Skrip et al. 2015). However, fruit availability varies over time and space (Valdez-Hernández et al. 2010; Feldman and Dorantes 2017; Feldman et al. 2018; Gallinat et al. 2018). If birds arrive when fruit is scarce, they may need to adjust their behavior, such as stopping over for longer, to obtain a greater departure fuel load (Hedenström 2008; Alerstam 2011; Moore et al. 2017); the extent of a bird's behavioral adjustment may depend on migration timing (Ke et al. 2019). On the other hand, birds may respond to food scarcity by foregoing refueling, entirely, and relocate to a more productive site shortly after arrival (sensu Bayly et al. 2018). Thus, individual habitats can take on a variety of functions during migration based on a bird's energetic needs and a habitat's ability to meet those needs.

The different ways birds use local habitat during migration is exemplified by the classification schemes of Mehlman et al. (2005) and Bayly et al. (2018), both of which distinguish sites used primarily for resting from those used for resting and refueling. As Bayly et al. (2018) emphasize, only in refueling sites do migrants truly stopover, in the sense that they adopt behaviors that maximize departure fuel load and minimize overall migration time. It follows that, at rest sites, birds may behave similarly regardless of local food availability: they are transient, feed minimally, recover from adverse weather, if necessary, and simply wait until dusk to move on (Rappole and Warner 1976; Ma et al. 2013; Cohen et al. 2014; Moore 2018). Where any individual site lies along the rest to refuel gradient is not yet fully understood, though it might be related to geographic barriers that require a high energy load to cross (Bayly et al. 2012; Ferretti et al. 2019). Prior to crossing water bodies, for example, migrants-especially lean individuals-may rest briefly along the coast before relocating inland, presumably to seek more food-rich habitats (Deutschlander and Muheim 2009; Smolinsky et al. 2013). In contrast, after crossing, birds may be fat depleted (Moore and Kerlinger 1987), which leads to a high concentration of individuals in coastal habitats (Lafleur et al. 2016; Clipp et al. 2020; Cohen et al. 2021) where they may refuel (Moore et al. 2017), take long stopovers (Dossman et al. 2016), and move among coastal habitats (Deutschlander and Muheim 2009). Importantly, lean birds are known to gain more mass and take longer stopovers than heavier birds (Moore and Kerlinger 1987; Loria and Moore 1990; Dossman et al. 2018) because there may be a minimum fuel load to attain before a bird can move on, depending on the distance that needs to be covered. On the other hand, it is also known that if the coast-including offshore islands-is food poor compared to the mainland interior, stopover may be short with birds relocating inland (Woodworth et al. 2014; Lupi et al. 2017; Maggini et al. 2020). Thus, it may be difficult to generalize the degree to which coastal habitats-and the food resources they contain-influence a bird's migratory schedule.

Increasing stopover duration may not be the only mechanism to increase departure fuel load. When the rate of food intake is low, birds may shorten stopover duration suggesting that they expand their search radius (Schaub et al. 2008). Similarly, instead of adjusting stopover duration, birds may adjust their foraging activity, devoting more or less of their day in the search for and consumption of food. In general, birds do not forage at their theoretical maximum because high body mass increases predation risk (Macleod et al. 2005; Cimprich and Moore 2006). However, if predation risk is low or starvation risk is high, then birds may feed constantly through the day (Bonter et al. 2013). Although predation is a real threat during migration (e.g. Zenzal et al. 2013), the pressure to build mass to migrate at night-as opposed to just surviving the night (Lind and Cresswell 2006) - may mean birds respond more strongly to food availability than predation. Whether birds adjust daily foraging activity during migratory stopover, especially in response to natural changes in food availability, has not been extensively explored. In spring, Smith et al. (2007) found that American Redstarts (Setophaga ruticila) foraged at higher rates in habitats with higher aquatic insect and spider biomass. Meanwhile in fall, migrants are known to make more searching maneuvers when foraging on arthropods than fruit (Parrish 2000; Schofield et al. 2018). Consequently, Smith and McWilliams (2014) 
found that lean Hermit Thrushes (Catharus guttatus) increased the amount of area they covered as fall progressed, which coincided with declining fruit availability. However, Smith and McWilliams (2014) used date as a proxy for fruit availability, which only gives a rough index of how birds respond to variation in fruit availability.

In North America, the Gulf of Mexico is a major migratory corridor connecting temperate breeding and tropical wintering grounds (La Sorte et al. 2016; Cohen et al. 2017; Horton et al. 2019). Much of our knowledge of the factors that influence stopover behavior before and after crossing geographic barriers come from the Gulf's north coast in the United States (e.g. Moore et al. 2005, 2017; Cohen et al. 2021). In contrast, there have been few studies documenting how birds recover after having made the crossing to the Gulf's south coast in the Yucatan Peninsula. Radio-tracking has revealed that birds require, on average, about $22 \mathrm{~h}$ to make the over water crossing (Deppe et al. 2015). Solomon (2016) found that fall migrating Swainson's Thrushes (Catharus ustulatus), Gray Catbirds (Dumetella carolinensis), Prothonotary Warblers (Protonotaria citrea), and Red-eyed Vireos (Vireo olivaceous) stopped over for an average of almost four days on an island off the Yucatan coast. However, the stopover duration was comparable to a nearby inland site and many individuals maintained or gained mass and departed the island in a seasonally appropriate direction, although less so for Red-eyed Vireos than the other species. Hence, it is possible that some individuals used the island site to refuel. Similarly, many migrants crossing the Gulf in good weather may fly past the coast (Gauthreaux 1971) but Red-eyed Vireos may be especially sensitive to weather (Deppe et al. 2015) and thus, be more likely to use coastal habitats. Whether vireo stopover duration in the Yucatan was longer when food was more abundant is an intriguing hypothesis worth testing. Given that migrants arriving to the island were fat depleted compared to inland (Solomon 2016), a phenomenon also observed on the Gulf of Mexico's north coast (Buler and Moore 2011; Lafleur et al. 2016; Cohen et al. 2020), then food availability, including fruit, on the Yucatan coast might have a disproportionate influence on migration success for trans-Gulf migrants.

To fill the knowledge gap about how birds respond to variation in food availability after crossing a large geographic barrier, we measured stopover duration and daily activity of the Red-eyed Vireo in autumn in two sites on the coast of the Yucatan Peninsula. At the same time, we measured temporal variation in fruit availability; under the assumption of a time minimization strategy (Alerstam 2011; Bayly et al. 2018), we expected an inverse relationship between stopover duration and fruit availability. We also expected leaner birds to take longer stopovers than heavier birds. Under an assumption that high fruit availability results in a more homogenous resource distribution and more localized foraging, we expected activity levels to decline with increasing fruit availability. On the other hand, it is possible that most birds arriving at our sites do not refuel or abandon the site quickly if food is scarce (sensu Schaub et al. 2008); thus, we left open the possibility that stopover duration and activity would not consistently vary or even vary positively with fruit availability.

\section{Methods \\ Study sites}

We surveyed migratory birds in two locations on the north coast of the Yucatan Peninsula, Mexico (Fig. 1). One site $\left(21.530^{\circ} \mathrm{N}, 87.749^{\circ} \mathrm{W}\right)$ was in the Ría Lagartos Biosphere Reserve to the west of the town of El Cuyo in Yucatan State, Mexico (hereafter called El Cuyo). Data collection occurred within a $2.2 \mathrm{~km}$ wide barrier beach composed of coastal dune and mangrove vegetation (see also Deppe and Rotenberry 2005, 2008). The other site was in Isla Contoy National Park $\left(21.473^{\circ} \mathrm{N}, 86.788^{\circ} \mathrm{W}\right)$, a barrier island $16 \mathrm{~km}$ off the northeastern coast of the state of Quintana Roo, Mexico, and $34 \mathrm{~km}$ northeast of the city of Cancun. We collected data in a $0.1 \mathrm{~km}$ wide part of the Island that consisted of coastal dune and mangrove vegetation. The island lies where the Gulf of Mexico meets the Caribbean Sea. We expected to find Red-eyed Vireos in both dune and mangrove vegetation (Deppe and Rotenberry 2005).

\section{Tagging and tracking individual birds}

We set up mist-nets in 2016 and 2017 to capture birds as part of a larger fall migration monitoring study. At El Cuyo, we established 10-12 m long mist nets within a $500 \mathrm{~m}$ area. At Isla Contoy, we established 11-12 m long mist nets within a $500 \mathrm{~m}$ area. We opened nets every day without wind and/or rain and opportunistically outfitted Red-eyed Vireos, Prothonotary Warblers, Swainson's Thrushes, and Gray Catbirds with 0.56 g Pip1 Ag376 VHF radio tags (Lotek Wireless, Inc.). We affixed the radios to the back of the birds using eyelash adhesive (Raim 1978). Due to small sample sizes for the other species ( $\leq 6$ birds per site), we focused our study on Redeyed Vireos for which we had 11 (Isla Contoy 2016), 22 (Isla Contoy 2017), 16 (El Cuyo 2016), and 16 (El Cuyo 2017) individuals with radios. However, due to technical difficulties, the radio tag falling off, and two likely depredated birds, the number of birds for which we were able to obtain stopover duration data were 6 (Isla Contoy, 2016), 15 (Isla Contoy, 2017), 15 (El Cuyo, 2016), and 15 (El Cuyo 2017). For activity data, we restricted our analysis to birds that had at least $8 \mathrm{~h}$ of detection occurring 


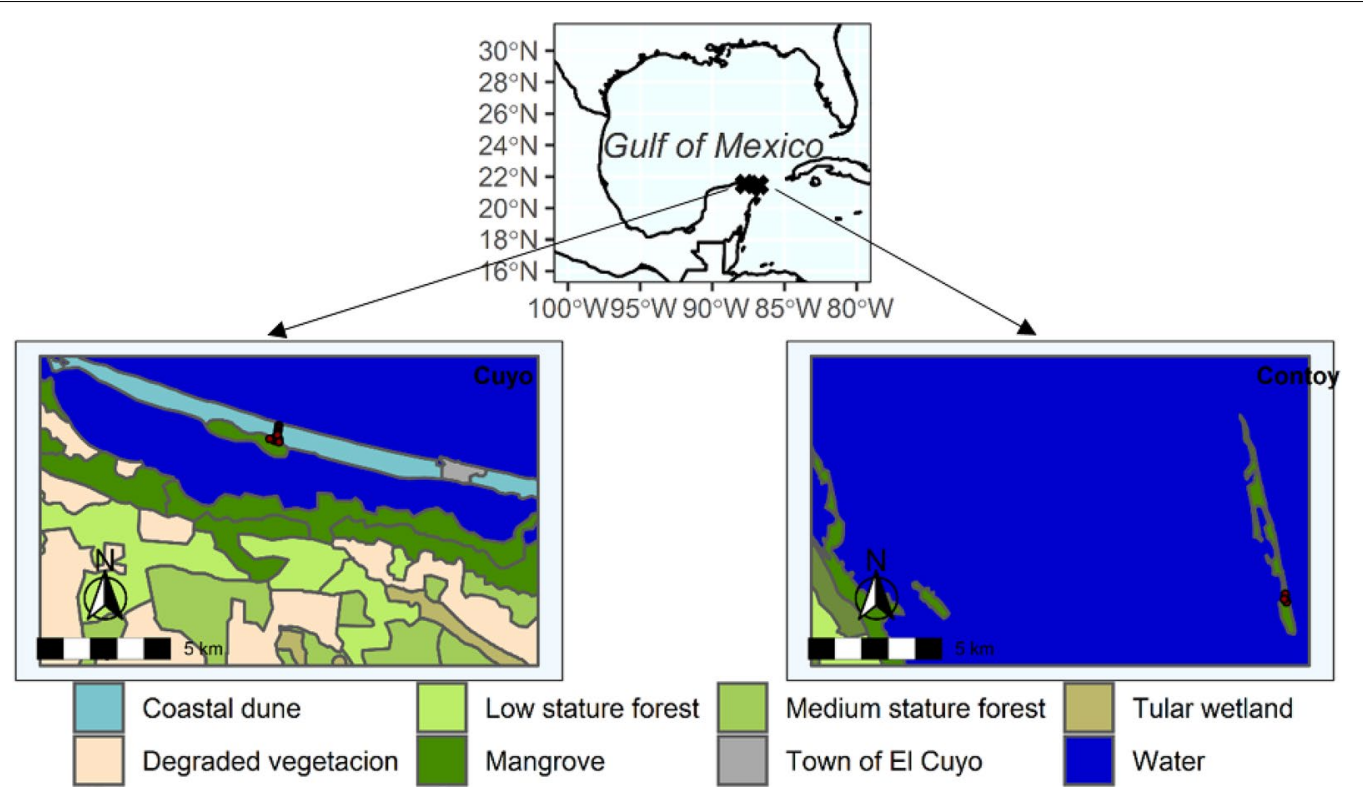

Fig. 1 The locations where Red-eyed Vireos were tagged and tracked on the north coast of the Yucatan Peninsula (top map). The lower maps indicate the mist net lanes (red dots) and vegetation composition of each site (data from the Instituto Nacional de Estadística y Geografía (Mexico) at a scale of 1:250,000 (https://www.inegi.org.mx/temas/usosuelo/))

on at least one calendar day. Thus, our sample sizes were 2 (Isla Contoy, 2016), 4 (Isla Contoy, 2017), 14 (El Cuyo, 2016), and 11 (El Cuyo 2017) birds. Given the low sample sizes at Isla Contoy, we decided not to analyze activity at that site. At El Cuyo, 10 of the 14 birds in 2016 and 2 of the 11 birds in 2017 had only one day with activity data.

Upon capture and prior to affixing the radios, we banded the birds and took standard measurements that aid in aging individuals based on Pyle (1997). In total, our data came from 29 hatch-year birds and 23 after hatchyear birds. We could not determine the sex of Red-eyed Vireos. We also weighed each bird using a digital scale. We used body mass as an index of fat content, assuming a strong correlation between the two metrics (sensu Lindström and Piersma 1993; Klaassen and Biebach 1994).

Once the birds were affixed with radio transmitters, we registered their location and activity using automated receiver units attached to a circular array of six Nighthawk brand yagi antennas. The units were mounted on the roof of a 10-m tall building (El Cuyo) and atop 10-m towers (El Cuyo and Isla Contoy). The receiver units were programmed with the frequencies of the transmitters attached to the birds and recorded the signal strength, noise, pulse width, and pulse interval of the transmitters every 1-6 min. For more details on using the automated tracking system to record bird activity see Schofield et al. (2018). We complemented automated tracking with manual tracking: every afternoon, we drove or walked up to $10 \mathrm{~km}$ from the banding locations while holding a receiving unit attached to a yagi antenna to search for a signal being emitted from a transmitter. The manual tracking allowed us to pick up birds that were not detected by the automatic system. For $4 / 6$ (Isla Contoy 2016), 14/15 (Isla Contoy 2017), 3/15 (El Cuyo 2016), and 5/15 (El Cuyo 2017) birds, we obtained later departure dates and times with the manual than automatic tracking. The difference in sites arose, in part, because the automatic unit at Isla Contoy was sometimes not programmed properly.

\section{Measuring stopover duration and daily activity}

We counted a bird as detected as opposed to the unit registering background noise if there were three consecutive measurements within $\pm 0.003 \mathrm{MHz}$ of the known radio frequency, the pulse width was within 3 ms of the known pulse width of the transmitter, the signal strength was greater than $125 \mathrm{db}$, and the noise was not greater than $130 \mathrm{db}$ (Deppe et al. 2015; Schofield et al. 2018).

Following Schofield et al. (2018) and the references cited therein, we distinguished active from sedentary birds by comparing the signal strength between two consecutive detections. If the difference exceeded $2.5 \mathrm{db}$, then we considered that the bird had moved between the two detections. We recorded the total time each bird was active for each hour of the day. We recorded the total stopover duration as the time between attaching the radio to the bird and the last automatic or manual detection. For 26 of 51 birds, we determined last detection via 
manual telemetry. To model daily activity, we summed our hourly activity data, only between the hours of 5 a.m. and 7 p.m. because activity was highly diminished outside of those hours.

\section{Fruit availability}

We measured fruit availability at each site in each year by walking along each of the $12-\mathrm{m}$ mist net lanes and counting all fleshy fruits up to $2 \mathrm{~m}$ on either side of the net lane. We classified fruits as being pre-ripe, ripe, and pastripe based on color and evidence of desiccation. During our two field seasons, Erithalis fruticosa produced 75\% of the mature fruit at Isla Contoy and Chiococca alba, Lantana involucrata, and Metopium brownei combined to produce $67 \%$ of the mature fruit at El Cuyo. Chrysobalanus icaco, Coccoloba uvifera, and Lantana involucrata and Acanthocereus tetragonus, Bonellia macrocarpa, Bursera simaruba, and Thrinax radiata produced smaller amounts of fruit at Isla Contoy and El Cuyo, respectively. We counted fruit weekly with 12-16 total samples, depending on the site and year. To calculate fruit density for the day each Red-eyed Vireo was captured and tagged, we averaged fruit density for that site and year but assigned greater weight to samples taken closer to the capture date. We calculated weight as the inverse square root of the distance between the bird capture date and each fruit counting date. Thus, fruit sampling dates closer in time to bird dates contributed more to fruit density values than fruit sampling dates farther away in time.

Given our fruit sampling regime, we were unable to quantify fruit spatial distribution. Hence, we assume that fruit abundance correlates with a homogenous resource distribution, thus promoting frugivory over insectivory and reducing searching time (Parrish 2000; Schofield et al. 2018). Similarly, we assume the fruits we sampled are part of the vireo diet: Red-eyed Vireos are known to consume fruit during fall migration elsewhere in their distribution (Parrish 1997; Cimprich et al. 2000) and the congeneric White-eyed Vireo ( $V$. griseus) is known to consume B. simarubra fruit in the Yucatan Peninsula (Greenberg et al. 1993, 1995).

\section{Data analysis}

Our small sample size (51 birds for stopover analysis and 25 birds for activity analysis) precluded running a full model with year, fruit density and body mass predictor variables and their interactions. Instead, we ran separate models for each study site and, for each site, compared the following models: an interaction between fruit density and year, an interaction between body mass and year, year only, and a null model without any predictors. We standardized the continuous predictor variables, centering by the mean and scaling by the standard deviation.
We compared the models using AICc and we inferred relationships for the model with the lowest AICc.

For the stopover model, we modeled observation level random error using a Gaussian distribution. For the activity model, we modeled observation level random error using a binomial distribution given that our data was the percentage of the day a bird was active. We included individual bird as a random intercept, given that we had up to eight days of activity data for an individual bird. Once we ran a model, we predicted stopover duration and daily activity for a range of fruit densities, body masses, and/or year depending on the model chosen by AICc. We ran and made predictions from the linear stopover model using base R 4.0.2 (R Core Team 2020). For the activity binomial mixed effects model, we used the (g)lmer function in the lme4 package (Bates et al. 2015) in R 4.0.2 (R Core Team 2020). We calculated prediction uncertainty by calculating the $95 \%$ prediction interval using the variance-covariance matrix of the model (see https://bbolker.github.io/mixedmodels-misc/glmmFAQ. html). When calculating prediction intervals, we did not include the uncertainty due to variance in random intercepts. All our R code is available as Additional file 1.

\section{Results}

Between the two sites, we found that birds were lighter at Isla Contoy than at El Cuyo and, on average, they passed through the site a little later (Table 1). Total and weekly average fruit density was higher at Isla Contoy in both years (Table 1). However, in all cases and years, the $95 \%$ confidence intervals of the estimates of the two sites

Table 1 Body mass and arrival dates for Red-eyed Vireos outfitted with radio transmitters and fruit density at our El Cuyo and Isla Contoy study sites in 2016 and 2017

\begin{tabular}{llll}
\hline Measure & Site & El Cuyo & Isla Contoy \\
\hline Individual body mass (g) & 2016 & $17.3 \pm 1.31$ & $16.5 \pm 0.880$ \\
& 2017 & $15.9 \pm 1.05$ & $14.5 \pm 0.776$ \\
Arrival day (Julian date) & 2016 & $266 \pm 8.63$ & $274 \pm 9.26$ \\
& 2017 & $257 \pm 7.60$ & $262 \pm 7.65$ \\
Total fruit density $\left(\# / \mathrm{m}^{2}\right)$ & 2016 & 2.71 & 3.50 \\
& 2017 & 2.45 & 3.31 \\
Mean fruit density $\left(\# /\left(\mathrm{m}^{2} \cdot \mathrm{wk}\right)\right)$ & 2016 & $0.226 \pm 0.157$ & $0.269 \pm 0.120$ \\
& 2017 & $0.175 \pm 0.0647$ & $0.207 \pm 0.0694$ \\
\hline
\end{tabular}

Data are expressed as mean $\pm 95 \%$ confidence interval, except for total fruit density, which is the sum of the fruit densities for the days Red-eyed Vireos were captured

Mean fruit density use counts from the weekly census conducted across all of fall migration

Sample sizes are six birds for Isla Contoy in 2016 and 15 birds for all other cases For the weekly fruit census, sample sizes are 12 and 14 for El Cuyo in 2016 and 2017, and 13 and 16 for Isla Contoy in 2016 and 2017. For all measures and years, the confidence intervals of the two sites overlap 
overlapped, indicating that site differences could potentially be due to sampling error.

In 2016, fruit density was negatively correlated with capture date at Isla Contoy (Pearson's correlation coefficient $\pm 95 \%$ confidence interval: $-0.859 \pm 0.125$; Fig. 2) and positively correlated with capture date at El Cuyo, though with uncertainty in the estimate of the direction and magnitude of the correlation (Pearson's correlation coefficient $\pm 95 \%$ confidence interval: $0.239 \pm 0.430$; Fig. 2). In 2017, fruit density was positively correlated with capture date at both sites (Pearson's correlation coefficient $\pm 95 \%$ confidence interval, Isla Contoy: $0.878 \pm 0.081$; El Cuyo: 0.677 \pm 0.206 ; Fig. 2).

\section{Stopover duration}

At El Cuyo, stopover duration varied widely (mean hours $\pm 95 \%$ confidence interval: $34.1 \pm 12.1, N=15$
(2016); $70.6 \pm 26.6, N=15$ (2017)). About half of the birds (9/15 in 2016 and 7/15 in 2017) departed on the same day they were captured. The other birds stayed between one and seven nights, with one exceptional bird in 2017 staying 16 nights (Fig. 3). At Isla Contoy, stopover duration was shorter (mean hours $\pm 95 \%$ confidence interval: $23.9 \pm 12.7, N=6$ (2016); $68.4 \pm 17.1$, $N=15$ (2017)), with $4 / 6$ in 2016 and 5/15 in 2017, departing the same day they were captured. The rest of the birds stayed between one and nine nights (Fig. 3).

Although, on average, stopover was longer in 2017 than 2016, variation in stopover duration could not be explained convincingly by year nor by fruit density or body mass. Instead, the null models had the lowest AICc (Table 2).

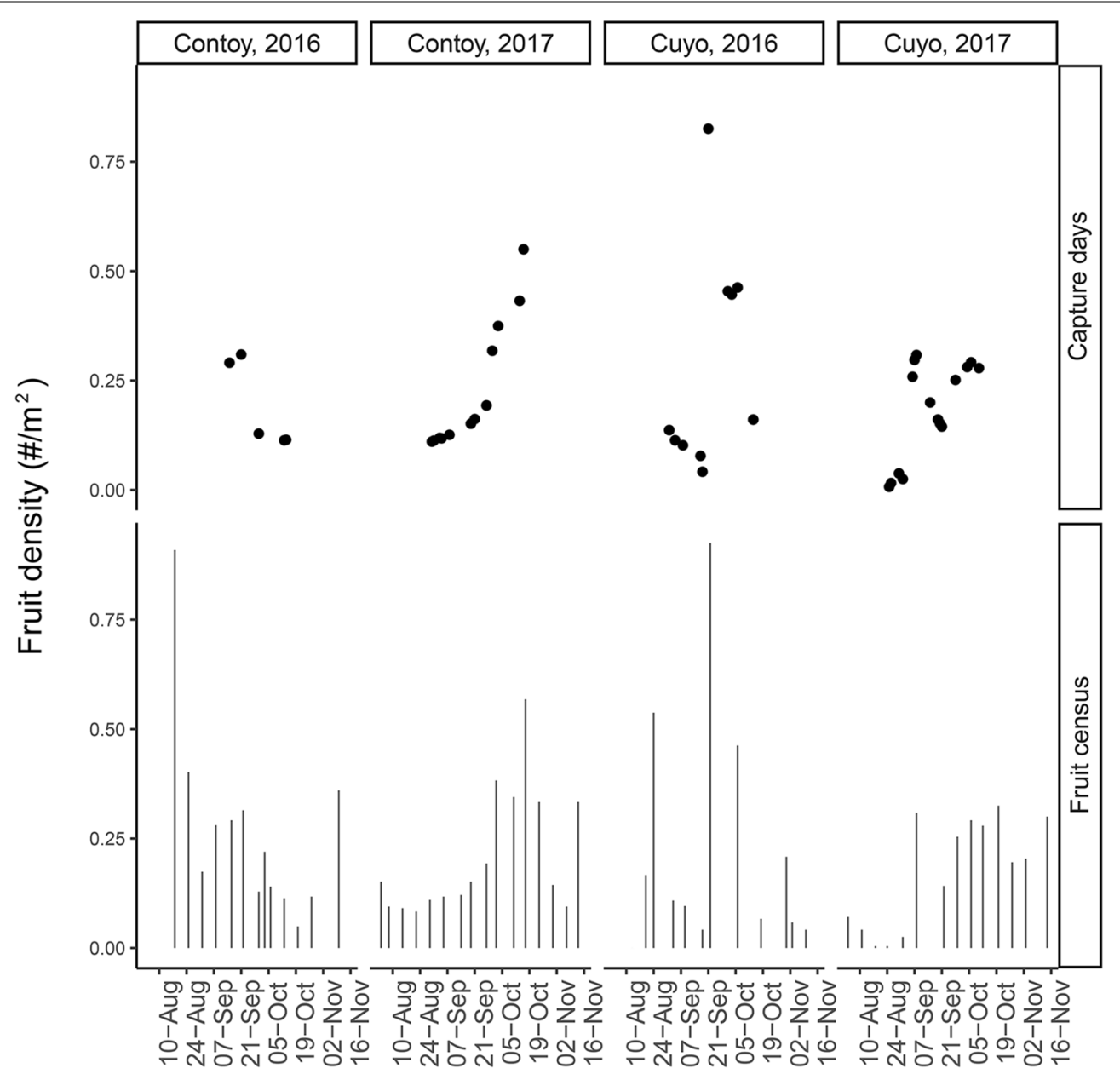

Fig. 2 Temporal variation in mature fruit density at two sites on the coast of the Yucatan Peninsula, Mexico. Fruit was counted in 10 (El Cuyo) and 11 (Isla Contoy) $12 \mathrm{~m} \times 4 \mathrm{~m}$ plots 12-16 times between August and November. The top panel ("Capture days") estimates fruit density for the days Red-eyed Vireos were captured and outfitted with radio tags. The bottom panel ("Fruit census") shows data from the days fruits were actually counted 


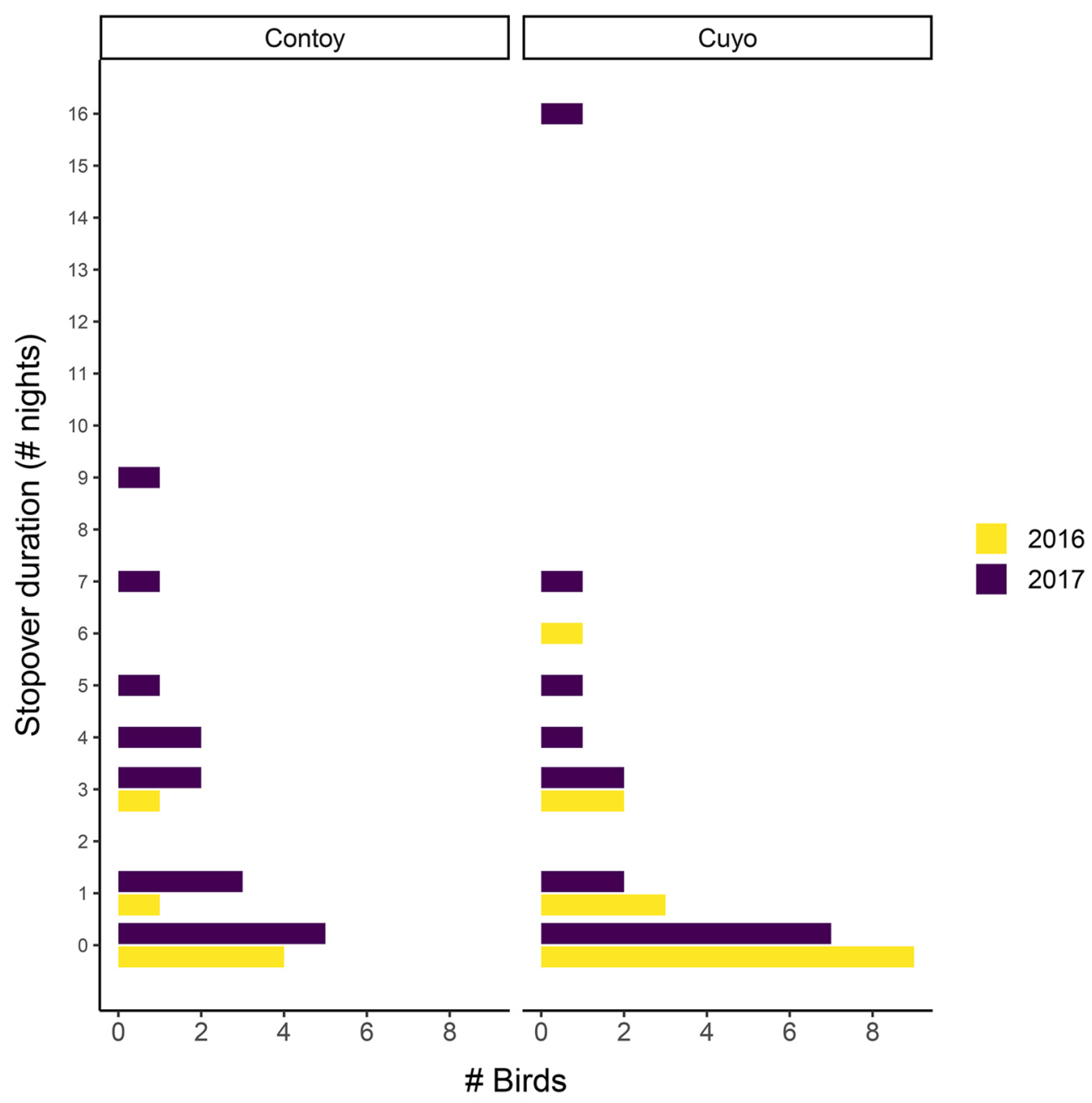

Fig. 3 Stopover duration expressed as number of nights for migrating Red-eyed Vireos at two sites and over two years during fall migration on the coast of the Yucatan Peninsula

\section{Activity levels}

We found little evidence that variation in daily activity at El Cuyo could be explained by fruit density. On the other hand, the model with the lowest AICc included body mass as a predictor variable, alongside its interaction with year (Table 2). Specifically, we found that daily activity decreased with increasing body mass and the relationship was stronger in 2016 than 2017 (Fig. 4). As a result, light birds had similar daily activity levels in both years but, for heavy birds, activity was greater in 2017 than 2016 (Fig. 4).

\section{Discussion}

Given the importance of fruit as a source of energy and antioxidants for migrating birds, we expected Red-eyed Vireos stopping over along the Gulf coast of the Yucatan Peninsula during fall migration to adjust their behavior-stopover duration, daily activity levels, or both-in response to naturally occurring temporal variability in fruit density. We did not find evidence of such a response because stopover duration tended to be short with most birds not even staying one night. For birds staying longer, our sample size was too small to discern the degree to which the decision to depart was associated with individual body mass or fruit density. For daily activity levels, however, we found evidence of a negative relationship between activity and individual body mass, though primarily for only one of the two years of our study.

Our results indicate that Red-eyed Vireos were transients (sensu Rappole and Warner 1976) likely using the Yucatan coast for nothing more than a quick rest after crossing the Gulf of Mexico. Having expended significant energy in an overwater flight that lasts approximately $22 \mathrm{~h}$ (Deppe et al. 2015), individuals may have focused their stopover on recuperating just enough energy to make a short flight to more productive 
Table 2 Comparing models hypothesized to explain variation in stopover duration (h) and daily activity (proportion of a day (500-1900 h) spent active) for Red-eyed Vireos at two sites over two years during fall migration on the coast of the Yucatan Peninsula

\begin{tabular}{|c|c|c|c|c|}
\hline $\begin{array}{l}\text { Stopover } \\
\text { behavior metric }\end{array}$ & Site & Model & AICc & $\triangle \mathrm{AICC}$ \\
\hline \multirow[t]{8}{*}{ Duration } & \multirow[t]{4}{*}{ Isla Contoy } & Null: $y \sim 1$ & 407.90 & 0.00 \\
\hline & & Year: $y \sim$ Year & 408.11 & 0.21 \\
\hline & & $\begin{array}{l}\text { Fruit density: } \\
y \sim \text { Fruit } \times \text { Year }\end{array}$ & 412.23 & 4.33 \\
\hline & & $\begin{array}{l}\text { Body mass: } \\
y \sim \text { Mass } \times \text { Year }\end{array}$ & 413.49 & 5.59 \\
\hline & \multirow[t]{4}{*}{ El Cuyo } & Null: $y \sim 1$ & 597.75 & 0.00 \\
\hline & & Year:y Year & 598.60 & 0.85 \\
\hline & & $\begin{array}{l}\text { Fruit density: } \\
y \sim \text { Fruit } \times \text { Year }\end{array}$ & 602.27 & 4.52 \\
\hline & & $\begin{array}{l}\text { Body mass: } \\
y \sim \text { Mass } \times \text { Year }\end{array}$ & 604.10 & 6.35 \\
\hline \multirow[t]{4}{*}{ Daily activity } & \multirow[t]{4}{*}{ El Cuyo } & Null: $y \sim 1$ & 3561.78 & 7.95 \\
\hline & & Year: $y \sim$ Year & 3558.58 & 4.75 \\
\hline & & $\begin{array}{l}\text { Fruit density: } \\
y \sim \text { Fruit } \times \text { Year }\end{array}$ & 3562.55 & 8.72 \\
\hline & & $\begin{array}{l}\text { Body mass: } \\
\text { y Mass } \times \text { Year }\end{array}$ & 3553.83 & 0.00 \\
\hline
\end{tabular}

The evidence for or against a model was assessed using Akaike's Information Criterion corrected for small sample size (AICC)

We did not analyze daily activity for birds at the Isla Contoy site because of low sample size

habitats rather than depositing enough fat to fuel a subsequent migratory flight (sensu Moore et al. 1990; Deutschlander and Muheim 2009). Alternatively, they have may simply rested until dusk before moving further inland: for the majority of birds we estimated departure as occurring between 6 and 10 p.m. (Isla Contoy 2016: 3/6; Isla Contoy 2017: 11/15; El Cuyo 2016: 13/15; El Cuyo 2017: 10/15; unpublished data). Short stopovers were also observed for Red-eyed Vireos in Nova Scotia, Canada: the majority of migrants relocated $3 \mathrm{~km}$ inland following stopover on an island likely because they were seeking sites with greater tree cover (Woodworth et al. 2014). At our El Cuyo site, birds only needed to cross a $\sim 4 \mathrm{~km}$ body of water to find inland forest, a preferred habitat for migrating Red-eyed Vireos (Suomala et al. 2010). Meanwhile, our Isla Contoy site is $\sim 16 \mathrm{~km}$ offshore but, still, most birds took short stopovers and likely departed to the interior mainland. In fact, for the seven birds with departure direction data, all were oriented between $190^{\circ} \mathrm{N}$ and $290^{\circ} \mathrm{N}$ (unpublished data), which would have them headed toward the mainland north of the city of Cancun. The finding is consistent with earlier data on Isla
Contoy's Red-eyed Vireos where half of the tagged birds departed in a seasonally inappropriate direction (Solomon 2016).

The decision to depart shortly after arrival may have been triggered by poor foraging conditions: individuals that lose energy or experience low rates of energy accumulation while on stopover are known to shorten stopover duration (Schaub et al. 2008; Schmaljohann and Eikenaar 2017). For the northern Yucatan Peninsula, we lack data that compares resource availability between coastal and inland sites. However, there is evidence that some individuals prefer to refuel inland. Solomon (2016) found that Red-eyed Vireos at Isla Contoy took shorter stopovers than at a nearby inland forest even though fat scores of captured birds were similar. At an inland site in the southeastern part of the Yucatan Peninsula in Belize, Johnson and Winker (2008) concluded that migrants, including Red-eyed Vireos, were stopping over to refuel and continue migration. Their Red-eyed Vireos had body masses (mean grams \pm standard deviation: $16.88 \pm 1.50$; Table 1 in Johnson and Winker (2008)) similar to our birds (Table 1). Poor foraging conditions could also arise if the vireos were not actually consuming some of the fruit species we sampled. Thus, we may have overestimated fruit availability. Foraging observations, fecal analysis, or metabarcoding could help to quantify fruit availability more precisely. In contrast, we may have underestimated fruit availability by only modeling ripe fruit. It is possible that birds also consume unripe fruits (Blake et al. 1990; but see Moermond and Denslow 1983; Blake and Loiselle 1991; Schaefer and Schmidt 2002; Schaefer and Schaefer 2006 for studies demonstrating preference for ripe over unripe fruit).

In contrast to our finding that most birds took short stopovers at our coastal sites, there was still a non-trivial number of birds that took longer stopover durations, including up to 16 days at El Cuyo. While it is possible that some birds moved laterally along the coast (sensu Deutschlander and Muheim 2009) or even back and forth between inland and coastal habitats, our El Cuyo activity data indicate that most birds likely stayed on site. Of the 8 birds that stayed more than one night, only two ever "disappeared" during daylight hours (i.e. had consecutive hours without activity being registered). The status of the bird that stayed 16 days was uncertain because its radio fell off and the individual was subsequently recaptured 9 days later. All but two of the birds that stayed one or less nights had activity registered hourly until their departure. By the same logic, birds we considered as having departed from the site likely left permanently instead of incorporating the site into an expanded foraging area.

A quick departure from resource poor sites should be more apparent for birds arriving at stopover in good 


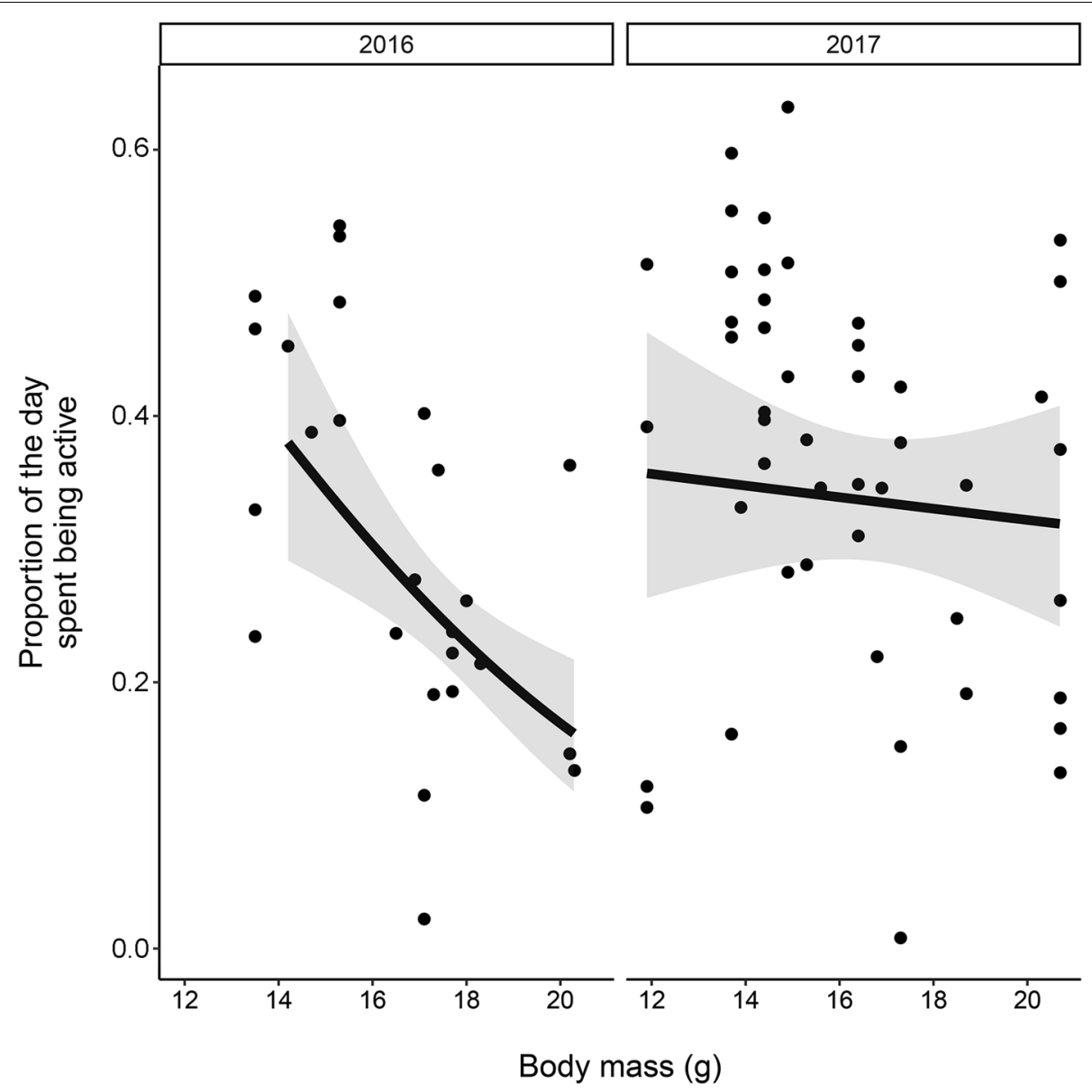

Fig. 4 The predicted relationship between body mass ( $\mathrm{g}$ ) and daily activity for Red-eyed Vireos at one study site and over 2 years during fall migration in the coastal Yucatan Peninsula. The shaded areas are the $95 \%$ confidence intervals of the predictions

condition (Klinner et al. 2020). However, instead of finding that light birds took longer stopovers, we found that they spent more of their day being active. Thus, Red-eyed Vireos needing to recuperate after crossing the Gulf may have chosen to increase fat mass by foraging more frequently rather than extending their stopover duration (see also Gwinner et al. 1988; Aborn and Moore 2004; Smith and McWilliams 2014). When vegetation cover is low, such as in our coastal dune habitats, migrants may depart quickly because of increased predation risk even if fruit is abundant (McCabe and Olsen 2015b). However, lighter birds may be more likely to forage in risky environments (Cimprich and Moore 2006). Hence it is possible that migrants avoid refueling in our coastal sites because of the predation risk and not necessarily because they have less food. Meanwhile, inland forests may provide the best of both worlds (sensu McCabe and Olsen 2015b): cover from predation and abundant food. We may also not have observed a difference in stopover duration between light and heavy birds because there was little individual variation in body mass and, in 2017, especially, all arriving individuals could be considered as being in poor body condition.

We found moderate evidence for differences in stopover duration between 2016 and 2017 with stopover being, on average, longer in 2017. The difference could reflect that, on average, birds were lighter in 2017 than 2016. As well, the difference could indicate better foraging conditions in 2017 because longer stopovers are associated with positive rates of fuel accumulation (Schaub et al. 2008; Lupi et al. 2017; Klinner et al. 2020). Although we did not find major differences in fruit density between 2016 and 2017, it is possible that we measured fruit density at too small a spatial scale or that our measure of fruit density did not reflect fuel deposition rates, which is the currency to which migrants adjust their stopover duration (Lindström and Alerstam 1992; Alerstam and Hedenström 1998). Similarly, by not measuring arthropod availability, we may have missed a key component of the vireo diet that influences stopover behavior (sensu 
Cohen et al. 2012). Higher activity levels in 2017 than 2016 could reflect greater arthropod availability because foraging for arthropods is thought to require more and longer movements than foraging on fruit (Parrish 2000; Schofield et al. 2018). Similarly, our finding that daily activity levels were similar between light and heavy birds in 2017 but not 2016 supports the assertion that food, and possibly arthropod, availability may have been greater in 2017 than 2016. When food is abundant, lean birds should reduce activity to similar levels as heavy birds, a pattern documented by Smith and McWilliams (2014), Lupi et al. (2017) and Ferretti et al. (2019).

\section{Conclusions}

Although migrating birds like Red-eyed Vireos may not be necessarily refueling and building mass in coastal Yucatan, it does not mean the habitats are unimportant. Many birds and bird species still land and forage in coastal habitats (Deppe and Rotenberry 2005, 2008) and our data show that some birds take extended stopovers. Clearly, more research is needed to determine if short stopovers are driven by food scarcity, high predation risk, or some other factor, especially given that climate change can affect food availability (Both et al. 2009). Similarly, more research is needed to determine whether migrants landing on the coast then move inland to refuel (sensu Johnson and Winker 2008). In this sense, we advocate thinking about stopover as a large-scale phenomenon, at least one that includes sites beyond where birds initially land (see also Smetzer and King 2018). Consequently, birds may rest and refuel in distinct sites and habitats and maintaining connectivity between them may be a crucial factor associated with migratory success and population health.

\section{Supplementary Information}

The online version contains supplementary material available at https://doi. org/10.1186/s40657-021-00299-w.

Additional file 1. R Code of the analysis used in the paper.

Additional file 2. A description of the data files included with the paper.

Additional file 3. The activity data used in the analysis, summarized from the raw data.

Additional file 4. Raw activity data for birds tagged at Isla Contoy in 2016. Additional file 5. Raw activity data for birds tagged at Isla Contoy in 2017. Additional file 6. Raw activity data for birds tagged at El Cuyo in 2016.

Additional file 7. Raw activity data for birds tagged at El Cuyo in 2017.

Additional file 8. The fruit density data used in the analysis.

Additional file 9. The stopover duration data used in the analysis.

Additional file 10. The fate of each bird outfitted with a VHF tag.

\section{Acknowledgements}

We thank J. Bobadilla, R. Duno, M. Fernández, M. Garcia, D. Guerrero, M. Martinez, and A. Montes for their tremendous effort conducting field work in hot and mosquito infested conditions. Our research would not have been possible without the logistical support of reserve directors C. Caceres and M. del C. Garcia. We thank D. Prosser and two anonymous reviewers for their comments on earlier manuscript drafts.

\section{Authors' contributions}

REF, ACM and JLD designed the study. REF, ACM, and MPW analyzed the data. REF, ACM, JLD, and MPW wrote the manuscript. All authors read and approved the final manuscript.

\section{Funding}

The research was supported by a joint grant from the Secretaria de Medio Ambiente y Recursos Naturales of Mexico and the Consejo Nacional de Ciencia y Tecnología of Mexico (\#262986).

\section{Availability of data and materials}

The datasets supporting the conclusions of this article are included within the article as Additional files 2, 3, 4, 5, 6, 7, 8, 9, 10 .

\section{Declarations}

\section{Ethics approval and consent to participate}

Permission to band birds was provided by the Secretaria de Medio Ambiente $y$ Recursos Naturales of Mexico under permit SGPA/DGVS/05989/16.

\section{Consent to participate}

Not applicable.

\section{Competing interests}

The authors declare that they have no competing interests.

\section{Author details}

${ }^{1}$ Centro de Investigación Científica de Yucatán, Unidad de Recursos Naturales, Merida, Yucatán, Mexico. ${ }^{2}$ Prairie Research Institute, Illinois Natural History Survey, University of Illinois, Urbana-Champaign, Illinois, USA. ${ }^{3}$ U.S. Geological Survey, Eastern Ecological Science Center, Patuxent Research Refuge, Laurel, MD, USA. ${ }^{4}$ National Audubon Society, Washington, DC, USA. ${ }^{5}$ Department of Natural Resources and Environmental Sciences, University of Illinois, Urbana-Champaign, Illinois, USA.

Received: 16 June 2021 Accepted: 3 November 2021 Published online: 20 November 2021

\section{References}

Aborn DA, Moore FR. Activity budgets of summer tanagers during spring migratory stopover. Wilson J Ornithol. 2004;116:64-8.

Alan RR, McWilliams SR, McGraw KJ. The importance of antioxidants for avian fruit selection during autumn migration. Wilson J Ornithol. 2013;125:513-25.

Alerstam T. Optimal Bird Migration Revisited. J Ornithol. 2011;152:5-23.

Alerstam T, Hedenström A. The development of bird migration theory. J Avian Biol. 1998;29:343-69.

Alerstam T, Lindström $\AA$. Optimal bird migration: the relative importance of time, energy and safety. In: Gwinner E, editor. Bird migration. Berlin: Springer-Verlag; 1990. p. 331-51.

Bairlein F. Fruit-eating in birds and its nutritional consequences. Comp Biochem Phys A. 1996;113:215-24

Bairlein F. The effect of diet composition on migratory fuelling in Garden Warblers Sylvia borin. J Avian Biol. 1998;29:546-51.

Bairlein F. How to get fat: nutritional mechanisms of seasonal fat accumulation in migratory songbirds. Naturwissenschaften. 2002;89:1-10.

Bates D, Maechler M, Bolker BM, Walker S. Fitting linear mixed-effects models using Ime4. J Stat Softw. 2015;67:1-48. 
Bayly NJ, Atkinson PW, Rumsey SJR. Fueling for the Sahara crossing: variation in site use and the onset and rate of spring mass gain by 38 Palearctic migrants in the western Sahel. J Ornithol. 2012;153:931-5.

Bayly NJ, Rosenberg KV, Easton WE, Gómez C, Carlisle J, Ewert DN, et al. Major stopover regions and migratory bottlenecks for Nearctic-Neotropical landbirds within the Neotropics: a review. Bird Conserv Int. 2018;28:1-26.

Blake JG, Loiselle BA. Variation in resource abundance affects capture rates of birds in three lowland habitats in Costa Rica. Auk. 1991;108:114-30.

Blake JG, Loiselle BA, Moermond TC, Levey DJ, Denslow JS. Quantifying abundance of fruits for birds in tropical habitats. Stud Avian Biol. 1990;13:73-9.

Bolser JA, Alan RR, Smith AD, Li L, Seeram NP, McWilliams SR. Birds select fruits with more anthocyanins and phenolic compounds during autumn migration. Wilson J Ornithol. 2013;125:97-108.

Bonter DN, Zuckerberg B, Sedgwick CW, Hochachka WM. Daily foraging patterns in free-living birds: exploring the predation-starvation trade-off. Proc R Soc B Biol Sci. 2013;280:20123087.

Both C, van Asch M, Bijlsma RG, van den Burg AB, Visser ME. Climate change and unequal phenological changes across four trophic levels: constraints or adaptations? J Anim Ecol. 2009;78:73-83.

Buler JJ, Moore FR. Migrant-habitat relationships during stopover along an ecological barrier: extrinsic constraints and conservation implications. J Ornithol. 2011;152:101-12.

Buler JJ, Moore FR, Woltmann S. A multi-scale examination of stopover habitat use by birds. Ecology. 2007:88:1789-802.

Cimprich DA, Moore FR. Fat affects predator-avoidance behavior in Gray Catbirds (dumetella carolinensis) during migratory stopover. Auk. 2006;123:1069-76.

Clipp HL, Cohen EB, Smolinsky JA, Horton KG, Farnsworth A, Buler JJ. Broadscale weather patterns encountered during flight influence landbird stopover distributions. Remote Sens. 2020;12:565.

Cohen EB, Moore FR, Fischer R. Experimental evidence for the interplay of exogenous and endogenous factors on the movement ecology of a migrating songbird. PLoS ONE. 2012;7: e41818.

Cohen EB, Moore FR, Fischer RA. Fuel stores, time of spring, and movement behavior influence stopover duration of Red-eyed Vireo Vireo olivaceus. J Ornithol. 2014;155:785-92.

Cohen EB, Barrow WC, Buler JJ, Deppe JL, Farnsworth A, Marra PP, et al. How do en route events around the Gulf of Mexico influence migratory landbird populations? Condor. 2017;119:327-43.

Cohen EB, Horton KG, Marra PP, Clipp HL, Farnsworth A, Smolinsky JA, et al. A place to land: spatiotemporal drivers of stopover habitat use by migrating birds. Ecol Lett. 2021;24:38-49.

Dänhardt J, Lindström Å. Optimal departure decisions of songbirds from an experimental stopover site and the significance of weather. Anim Behav. 2001;62:235-43.

Deppe JL, Rotenberry JT. Temporal patterns in fall migrant communities in Yucatan, Mexico. Condor. 2005;107:228-43.

Deppe JL, Rotenberry JT. Scale-dependent habitat use by fall migratory birds: vegetation structure, floristics, and geography. Ecol Monogr. 2008;78:461-87.

Deppe JL, Ward MP, Bolus RT, Diehl RH, Celis-Murillo A, Zenzal TJ, et al. Fat, weather, and date affect migratory songbirds' departure decisions, routes, and time it takes to cross the Gulf of Mexico. Proc Natl Acad Sci USA. 2015;112:E6331-8.

Deutschlander ME, Muheim R. Fuel reserves affect migratory orientation of thrushes and sparrows both before and after crossing an ecological barrier near their breeding grounds. J Avian Biol. 2009;40:85-9.

Dossman BC, Mitchell GW, Norris DR, Taylor PD, Guglielmo CG, Matthews SN, et al. The effects of wind and fuel stores on stopover departure behavior across a migratory barrier. Behav Ecol. 2016;27:567-74.

Dossman BC, Matthews SN, Rodewald PG. An experimental examination of the influence of energetic condition on the stopover behavior of a Nearctic-Neotropical migratory songbird, the American Redstart (Setophaga ruticilla). Auk. 2018;135:91-100.

Feldman RE, Dorantes EA. La fenología de frutos de la duna costera de la Península de Yucatán. Desde Herb CICY. 2017;9:77-82.

Feldman RE, Žemaitè I, Miller-Rushing AJ. How training citizen scientists affects the accuracy and precision of phenological data. Int J Biometeorol. 2018;62:1421-35
Ferretti A, Maggini I, Lupi S, Cardinale M, Fusani L. The amount of available food affects diurnal locomotor activity in migratory songbirds during stopover. Sci Rep. 2019;9:19027.

Gallinat AS, Primack RB, Willis CG, Nordt B, Stevens AD, Fahey R, et al. Patterns and predictors of fleshy fruit phenology at five international botanical gardens. Am J Bot. 2018;105:1824-34.

Gauthreaux SA. A radar and direct visual study of passerine spring migration in southern Louisiana. Auk. 1971;88:343-65.

Greenberg R, Niven DK, Hopp S, Boone C. Frugivory and coexistence in a resident and a migratory vireo on the Yucatan Peninsula. Condor. 1993;95:990-9.

Greenberg R, Foster MS, Marquez-Valdelamar L. The role of the White-Eyed Vireo in the dispersal of Bursera fruit on the Yucatan Peninsula. J Trop Ecol. 1995;11:619-39.

Gwinner E, Schwabl H, Schwabl-Benzinger I. Effects of food-deprivation on migratory restlessness and diurnal activity in the garden warbler Sylvia borin. Oecologia. 1988;77:321-6.

Hedenström A. Adaptations to migration in birds: behavioural strategies, morphology and scaling effects. Philos Trans R Soc B Biol Sci. 2008;363:287-99.

Horton KG, Van Doren BM, La Sorte FA, Cohen EB, Clipp HL, Buler JJ, et al. Holding steady: little change in intensity or timing of bird migration over the Gulf of Mexico. Glob Chang Biol. 2019;25:1106-18.

Johnson AB, Winker K. Autumn stopover near the Gulf of Honduras by Nearctic-Neotropic migrants. Wilson J Ornithol. 2008;120:277-85.

Ke WJ, He P, Peng HB, Choi CY, Zhang SD, Melville DS, et al. Migration timing influences the responses of birds to food shortage at their refuelling site. ibis. 2019;161:908-14.

Klaassen M, Biebach $\mathrm{H}$. Energetics of fattening and starvation in the longdistance migratory garden warbler, Sylvia borin, during the migratory phase. J Comp Physiol B. 1994;164:362-71.

Klinner T, Buddemeier J, Bairlein F, Schmaljohann H. Decision-making in migratory birds at stopover: an interplay of energy stores and feeding conditions. Behav Ecol Sociobiol. 2020;74:10.

La Sorte FA, Hochachka WM, Farnsworth A, Sheldon D, Fink D, Geevarghese J, et al. Migration timing and its determinants for nocturnal migratory birds during autumn migration. J Anim Ecol. 2015;84:1202-12.

La Sorte FA, Fink D, Hochachka WM, Kelling S. Convergence of broad-scale migration strategies in terrestrial birds. Proc R Soc B. 2016;283:20152588.

Lafleur JM, Buler JJ, Moore FR. Geographic position and landscape composition explain regional patterns of migrating landbird distributions during spring stopover along the northern coast of the Gulf of Mexico. Landscape Ecol. 2016;31:1697-709.

Lind J, Cresswell W. Anti-predation behaviour during bird migration; the benefit of studying multiple behavioural dimensions. J Ornithol. 2006:147:310-6.

Lindström $\AA$, Alerstam T. Optimal fat loads in migrating birds: a test of the time-minimization hypothesis. Am Nat. 1992;140:477-91.

Lindström Å, Piersma T. Mass changes in migrating birds: the evidence for fat and protein storage re-examined. Ibis. 1993;135:70-8.

Loria DE, Moore FR. Energy demands of migration on red-eyed vireos Vireo Olivaceus. Behav Ecol. 1990;1:24-35.

Lupi S, Maggini I, Goymann W, Cardinale M, Rojas Mora A, Fusani L. Effects of body condition and food intake on stop-over decisions in Garden Warblers and European Robins during spring migration. J Ornithol. 2017;158:989-99.

Ma Z, Hua N, Peng H-B, Choi C, Battley PF, Zhou Q, et al. Differentiating between stopover and staging sites: functions of the southern and northern Yellow Sea for long-distance migratory shorebirds. J Avian Biol. 2013:44:504-12.

Macleod R, Barnett P, Clark JA, Cresswell W. Body mass change strategies in blackbirds Turdus merula: the starvation-predation risk trade-off. J Anim Ecol. 2005;74:292-302.

Maggini I, Trez M, Cardinale M, Fusani L. Stopover dynamics of 12 passerine migrant species in a small Mediterranean island during spring migration. J Ornithol. 2020;161:793-802.

Marra PP, Hobson KA, Holmes RT. Linking winter and summer events in a migratory bird by using stable-carbon isotopes. Science. 1998;282:1884-6. 
Marshall TJ, Dick MF, Guglielmo CG. Seasonal dietary shifting in yellow-rumped warblers is unrelated to macronutrient targets. Comp Biochem Physiol Physiol A Mol Integr Physiol. 2016;192:57-63.

McCabe JD, Olsen BJ. Landscape-scale habitat availability, and not local geography, predicts migratory landbird stopover across the Gulf of Maine. J Avian Biol. 2015a;46:395-405.

McCabe JD, Olsen BJ. Tradeoffs between predation risk and fruit resources shape habitat use of landbirds during autumn migration. Auk. 2015b:132:903-13.

McWilliams SR, Kearney SB, Karasov WH. Diet preferences of warblers for specific fatty acids in relation to nutritional requirements and digestive capabilities. J Avian Biol. 2002;33:167-74.

McWilliams SR, Guglielmo CG, Pierce BJ, Klaassen M. Flying, fasting, and feeding in birds during migration: a nutritional and physiological ecology perspective. J Avian Biol. 2004;35:377-93.

Mehlman DW, Mabey SE, Ewert DN, Duncan C, Abel B, Cimbrich D, et al. Conserving stopover sites for forest-dwelling migratory landbirds. Auk. 2005;122:1281-90.

Moermond TC, Denslow JS. Fruit choice in neotropical birds: effects of fruit type and accessibility on selectivity. J Anim Ecol. 1983;52:407-20.

Moore FR. Biology of landbird migrants: a stopover perspective. Wilson J Ornithol. 2018;130:1-12.

Moore FR, Kerlinger P. Stopover and fat deposition by North American woodwarblers (Parulinae) following spring migration over the Gulf of Mexico. Oecologia. 1987;74:47-54.

Moore FR, Kerlinger P, Simons TR. Stopover on a Gulf Coast barrier island by spring trans-gulf migrants. Wilson Bull. 1990;102:487-500.

Moore FR, Woodrey MS, Buler JJ, Woltmann S, Simons TR. Understanding the stopover of migratory birds: a scale dependent approach. In: Ralph CJ, Rich TD (eds.). Bird conservation implementation and integration in the Americas: proceedings of the third international partners in flight conference. USDA Forest Service General Technical Report PSW-GTR-191; Albany. 2005. p 684-9

Moore FR, Covino KM, Lewis WB, Zenzal TJ, Benson TJ. Effect of fuel deposition rate on departure fuel load of migratory songbirds during spring stopover along the northern coast of the Gulf of Mexico. J Avian Biol. 2017;48:123-32.

Norris DR, Marra PP, Kyser TK, Sherry TW, Ratcliffe LM. Tropical winter habitat limits reproductive success on the temperate breeding grounds in a migratory bird. Proc Biol Sci. 2004;271:59-64.

Parrish JD. Patterns of frugivory and energetic condition in Nearctic landbirds during autumn migration. Condor. 1997;99:681-97.

Parrish JD. Behavioral, energetic, and conservation implications of foraging plasticity during migration. Stud Avian Biol. 2000;20:53-70.

Paxton KL, Moore FR. Carry-over effects of winter habitat quality on en route timing and condition of a migratory passerine during spring migration. $J$ Avian Biol. 2015;46:495-506.

Pyle P. Identification guide to North American Birds. Part 1. Point Reyes: State Creek Press; 1997.

R Core Team. R: a language and environment for statistical computing. Vienna: R Foundation for Statistical Computing; 2020.

Raim A. A radio transmitter attachment for small passerines. Bird-Banding. 1978:49:326-32.

Rappole JH, Warner DW. Relationships between behavior, physiology and weather in avian transients at a migration stopover site. Oecologia. 1976;26:193-212.

Reed TE, Jenouvrier S, Visser ME. Phenological mismatch strongly affects individual fitness but not population demography in a woodland passerine. J Anim Ecol. 2013;82:131-44.
Schaefer HM, Schaefer V. The fruits of selectivity: how birds forage on Goupia glabra fruits of different ripeness. J Ornithol. 2006;147:638-43.

Schaefer HM, Schmidt V. Feeding strategies and food intake of Blackcaps (Sylvia atricapilla) consuming ripe or unripe fruits and insects. J Ornithol. 2002;143:341-50.

Schaub M, Jenni L, Bairlein F. Fuel stores, fuel accumulation, and the decision to depart from a migration stopover site. Behav Ecol. 2008;19:657-66.

Schmaljohann $\mathrm{H}$, Eikenaar C. How do energy stores and changes in these affect departure decisions by migratory birds? A critical view on stopover ecology studies and some future perspectives. J Comp Physiol A. 2017;203:411-29.

Schofield LN, Deppe JL, Zenzal TJ, Ward MP, Diehl RH, Bolus RT, et al. Using automated radio telemetry to quantify activity patterns of songbirds during stopover. Auk. 2018;135:949-63.

Sillett TS, Holmes RT. Variation in survivorship of a migratory songbird throughout its annual cycle. J Anim Ecol. 2002;71:296-308.

Skrip MM, Bauchinger U, Goymann W, Fusani L, Cardinale M, Alan RR, et al. Migrating songbirds on stopover prepare for, and recover from, oxidative challenges posed by long-distance flight. Ecol Evol. 2015;5:3198-209.

Smetzer JR, King DI. Prolonged stopover and consequences of migratory strategy on local-scale movements within a regional songbird staging area. Auk. 2018;135:547-60.

Smith SB, McWilliams SR. Patterns of fuel use and storage in migrating passerines in relation to fruit resources at autumn stopover sites. Auk. 2010;127:108-18.

Smith AD, McWilliams SR. What to do when stopping over: behavioral decisions of a migrating songbird during stopover are dictated by initial change in their body condition and mediated by key environmental conditions. Behav Ecol. 2014;25:1423-35.

Smith RJ, Moore FR. Arrival timing and seasonal reproductive performance in a long-distance migratory landbird. Behav Ecol Sociobiol. 2005;57:231-9.

Smith RJ, Moore FR, May CA. Stopover habitat along the shoreline of northern Lake Huron, Michigan: emergent aquatic insects as a food resource for spring migrating landbirds. Auk. 2007;124:107-21.

Smolinsky JA, Diehl RH, Radzio TA, Delaney DK, Moore FR. Factors influencing the movement biology of migrant songbirds confronted with an ecological barrier. Behav Ecol Sociobiol. 2013;67:2041-51.

Solomon LE. Stopover ecology of Neotropical migratory songbirds in the northern Yucatan Peninsula, Mexico. Master's Thesis. Charleston: Eastern Illinois University; 2016

Suomala RW, Morris SR, Babbitt KJ, Lee TD. Migrant songbird species distribution and habitat use during stopover on two islands in the Gulf of Maine. Wilson J Ornithol. 2010;122:725-37.

Valdez-Hernández M, Andrade JL, Jackson PC, Rebolledo-Vieyra M. Phenology of five tree species of a tropical dry forest in Yucatan, Mexico: effects of environmental and physiological factors. Plant Soil. 2010;329:155-71.

Wheelwright NT. Seasonal changes in food preferences of American robins in captivity. Auk. 1988;105:374-8.

Woodworth BK, Francis CM, Taylor PD. Inland flights of young red-eyed vireos Vireo olivaceus in relation to survival and habitat in a coastal stopover landscape. J Avian Biol. 2014;45:387-95.

Zenzal TJ, Fish AC, Jones TM, Ospina EA, Moore FR. Observations of predation and anti-predator behavior of Ruby-throated Hummingbirds during migratory stopover. Southeast Nat. 2013;12:N21-5. 